UDC 330.15:336

JEL Classification: O3, 013, E01, H23, N5

http://doi.org/10.21272/mmi.2018.4-22

Svetlana Vegera,

Ph.D., Associate Professor, Polotsk State University, Belarussia

Alena Malei,

Ph.D., Associate Professor, Polotsk State University, Belarussia

Olga Romanova,

Ph.D., Associate Professor, Polotsk State University, Belarussia

Volha Sushko,

Ph.D., Associate Professor, Polotsk State University, Belarussia

\title{
ENVIRONMENTAL INNOVATION AS A PART OF MINERAL RESOURCES ACCOUNTING AND FINANCIAL REPORTING DEVELOPMENT FOR NATURAL CAPITAL INVOLVEMENT IN MANAGEMENT DECISION-MAKING PROCESS
}

Abstract. Natural capital involvement in the management decision-making process of business entities by reforming current accounting and reporting methodology is an environmental innovation because it forces the organization's management to use such business methods that reduce the negative impact on the environment and ensure rational use of natural resources. An important part of natural capital is mineral resources, the data on which nowadays is not reflected in the accounting and reporting of organizations - subsoil users, what determines the relevance of the research topic. The purpose of this study is theoretical substantiation and recommendations for the development of mineral resources accounting methods and improving the accounting (financial) statements forms of organizations-subsoil users in the context of the natural capital concept. Among the methods used in the study, the authors identify synthesis, analysis, comparison, logical generalization, the conclusion by analogy, classification, grouping, etc. As part of accounting and reporting system development in terms of data formation about mineral resources used, the article investigates the economic essence of the concepts "minerals", "mineral reserves", "mineral resources", and "mineral raw materials", and proves their identity / non-identity. A three-dimensional classification has been developed in order to identify mineral resources from which economic benefits are expected. It has been proved that mineral resources can be an object of accounting since it is established that all criteria for recognition as an asset are fulfilled simultaneously in their relation. For accounting of natural capital use and organization's activities indicators connection, the article proposes a new dual model of accounting and reflection in accounting (financial) statements of mineral resources, which allows to present information on natural capital to interested users in two aspects. 'the cost of attracting mineral resources and economic potential of used mineral resources, which will eliminate the distortion of the information provided and provide information basis for relevant areas of analysis. Also, within the framework of the justified need for mineral resources accounting, the authors developed the recommendations for improving the content of accounting (financial) reporting forms of organizations - subsoil users, providing information about the organization's natural capital used and its depletion, which increases the information value of reporting, its forecast characteristics and takes on particular importance when making management decisions in the field of rational subsoil use.

Keywords: environmental innovation, natural capital, mineral resources, subsoil users.

Introduction. Nowadays the world community has recognized that short-term benefits prevail over long-term objectives of the social life improving in the activities of many economic actors, what leads to the use of mechanisms for more aggressive decision-making in the field of environmental management. That fact leads to economic, social and environmental crises of various scales and does not contribute to the stable development of national economies. Growing attention of the world community to the environmental imperative of sustainable development requires the reflection of system interconnection

Cite as: Vegera, S., Malei, A., Romanova, O., \& Sushko, V. (2018). Environmental Innovation as a Part of Mineral Resources Accounting and Financial Reporting Development for Natural Capital Involvement in Management Decision-Making Process. Marketing and Management of Innovations, 4, 244-262. http://doi.org/10.21272/mmi.2018.4-22 
S. Vegera, A. Malei, O. Romanova, V. Sushko. Environmental Innovation as a Part of Mineral Resources Accounting and Financial Reporting Development for Natural Capital Involvement in Management Decision-Making Process

between environmental resources and economic results both at the macro level - within the system of national accounts and at microeconomic level - in the accounting system of a separate organization.

The involvement of natural capital in the management decision-making process of business entities by reforming current accounting and reporting methodology is environmental innovation because it forces the organization's management to use such business methods that reduce the negative impact on the environment and ensure the rational use of natural resources.

The perceived need to include the information on the use of natural capital in accounting system is relevant for many countries of the world community, as evidenced by the report "Natural Capital: Evidence Overlooked" (June 2014), prepared by the Institute of Chartered Accountants in the field of management accounting with the company "Ernst\&Young", International Federation of Accountants and the Natural Capital Association (The depletion of natural capital, 2014); natural capital declaration signed by 75 countries and the European Commission during the work of the UN Conference on Sustainable Development "Rio + 20" (June 2012) (Mass demonstration of support for measures to account for natural capital, 2012). All this as well the publication of the document "Extractive Activities" by the International Financial Reporting Standards Board, which raises questions of the assessment and classification of discovered minerals, the requirements for disclosing information related to the extractive activities.

Also, a lot of attention is paid to the rational use of mineral resources as the basis of material production and the national security of the country in the Republic of Belarus. Thus, in accordance with the National Security Concept of the Republic of Belarus, the main threats are the exhaustion of mineral resources, the low level of self-sufficiency of resources, and the insufficient development of natural resource accounting systems (On approval of the National Security Concept, 2010). The strategy for the development of the geological industry and the intensification of the mineral resource base development in the Republic of Belarus until 2025 provides for the development of economic mechanism for resource use, as well as the development of economic indicators system to evaluate the effectiveness of the mineral resources involvement in economic circulation, increasing economic responsibility in making appropriate management decisions (Development strategy of the geological industry, 2013).

An important factor in the development of an effective management system for rational subsoil use at the microeconomic level is the availability of comprehensive accounting in the oil-gas and mining industries. Nowadays, subsoil users do not reflect data on mineral reserves in accounting and reporting. This leads to distortion of information about the resource potential of organization and its depletion, the lack of the necessary information base to assess the investment attractiveness of company, and also does not allow the accumulate this information in the system of national accounts. Various aspects of the inclusion in accounting and reporting of information on the use of natural capital are considered in the works of foreign and domestic authors (Yu. V. Altukhova, 2010, I. V. Zamula, 2010, J. Richard, 2000, A. P. Shevlyukov, 2009).

The study of accounting and reporting issues in oil and gas and mining organizations is devoted to the work of authors (R. A. Gallan, S. Wright, 2007, D. Johnston, 2005, M. A. Mygkih, 2006, V.T. Chaya, 2010, Ch. T. Horngren, 1995). The problems of recording the costs of exploration and appraisal are solved in different works (M. I. Agoshkov, 1974, V. F. Dunaev, 1983, N. V. Zyleva, 2015, A. Kh. Ibragimova, 2015, P. G. Egorin, 1988, A. Yu. Popov, 2013). In the Republic of Belarus, research in this area was not conducted. Theoretical and methodological issues of economic evaluation of mineral deposits and the effectiveness of their development are considered in the studies of Belarusian authors (A. V. Unukovich, 2012, P. B. Tsalko, 2011).

The analysis of foreign and domestic publications suggests that the main unresolved problem is the lack of the system that takes into account the relationship between indicators of the use of natural capital and economic results of a business entity. This problem is especially relevant for resource-oriented types of economic activity, in particular for oil and gas and mining organizations, since the cost of the most 
S. Vegera, A. Malei, O. Romanova, V. Sushko. Environmental Innovation as a Part of Mineral Resources Accounting and Financial Reporting Development for Natural Capital Involvement in Management Decision-Making Process

significant asset of such business entities, mineral reserves, is not reflected in accounting (financial) statements, which is not consistent with the principle of economic priority content over the legal form, distorts the indicators of the resource potential, the investment attractiveness of organization.

To solve the problem of including the factor of mineral resources as part of natural capital in the decision-making process, rational use of mineral resources requires further development of the existing accounting and reporting system, which determined the purpose of the study: theoretical substantiation and development of recommendations for the development of methods of accounting for mineral resources and improving forms accounting (financial) statements of subsoil users in the context of the natural capital concept. This goal can be achieved through the following tasks:

- scientifically substantiate the economic nature and composition of mineral resources as accounting objects;

- to develop a model for reflecting information on mineral resources in accounting and reporting of subsoil users, that will allow presenting data on the natural capital used in two aspects: the cost of attracting mineral resources and the economic potential of the mineral resources used;

- to develop a methodology for mineral resources accounting at the current market value as part of natural capital;

- to develop recommendations for improving the forms of accounting (financial) statements of subsoil users.

The object of the research is mineral resources (mineral reserves). The choice of the object of the research is due to the relevance of the issues of reflection in the accounting and reporting of information about mineral resources, their insufficient development and practical significance in modern conditions.

It is necessary to mention that this research also is based on the study of policy documents, special economic and scientific literature, connected with the chosen topic of research. The research is theoretically based on different standards and literature in the field of using natural capital, rational and effective use of mineral resources in the Republic of Belarus and countries of the European Space. Among the methods used in the research, the authors identify synthesis, analysis, comparison, inference by analogy, classification, grouping, critical assessment, systematization and logical generalization.

The economic nature and composition of mineral resources as objects of accounting. The need to develop an accounting and reporting system in terms of the data formation about mineral resources used requires, first of all, the refinement of scientific terminology. Legislative and regulatory documents of various countries, international financial reporting standards, special literature on the use of mineral resources use different, sometimes contradictory wordings of the terms "minerals", "mineral reserves", "mineral resources", and "mineral raw materials". As a result of the analysis of the existing points of view on the definition of the economic content of the categories "minerals" and "mineral raw materials", three approaches can be distinguished. According to the first, minerals are understood to be natural mineral formations of inorganic or organic origin contained in the depths, the properties of which allow their industrial and other economic use. And mineral raw materials are minerals extracted from the subsoil and subjected to primary processing (purification, enrichment) (Code of the Republic of Belarus on Subsoil, 2008, Mining Law of Ukraine, 1999, Sekisov, G. V., 1994). In accordance with the second, opposite, point of view, minerals are already treated as products of the mining industry, contained in the mineral raw materials extracted from the depths (On Subsoil and Subsoil Use, 2010, Tax Code of the Russian Federation, 2000). The third approach to the interpretation of these terms provides for their identity (Shimova, O. S., 2012, Prokhorov, A. M., 1975). In addition to the term's "minerals" and "mineral raw materials" in the special literature and regulatory legal acts of different countries, the concepts of "mineral resources" and "mineral reserves" are used, in the definition of which there are also contradictions. In this regard, a study was conducted of the essence of these definitions, set out in the special economic literature, as well as regulatory legal acts of different countries, in order to determine the economic content 
S. Vegera, A. Malei, O. Romanova, V. Sushko. Environmental Innovation as a Part of Mineral Resources Accounting and Financial Reporting Development for Natural Capital Involvement in Management Decision-Making Process

of accounting objects and to analyse the key features of each category. The results of this study allowed to establish their identity/non-identity, to correlate each category with the stage of the life cycle of the field development (Figure 1).

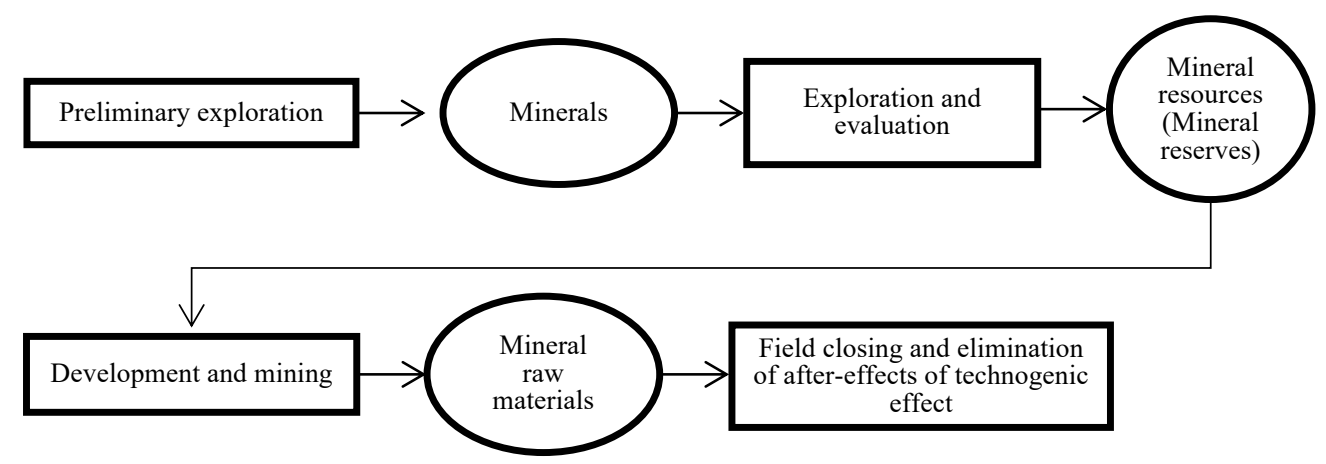

Figure 1 - The ratio of the stages of the life cycle of the development of the field and the economic essence of the concepts "minerals", "mineral reserves", "mineral resources", "mineral raw materials"

Sources: authors' development based on the theoretical study and comparison of literary sources, regulatory legal acts.

Thus, as a result of preliminary exploration, minerals are identified that are predicted natural mineral formations of inorganic or organic origin, which are located in the depths, and which are possible to be economically used with varying degrees of probability. After geological exploration, minerals are transformed into mineral resources (mineral reserves), the use of which is proved on the basis of a quantitative assessment. And in the process of extracting, mineral resources (mineral reserves) are transferred to mineral raw materials, that is, identified and quantified minerals extracted from the depths.

Consider each category in terms of the possibility of reflection in the accounting system and reporting in organizations of subsoil users. In our opinion, minerals cannot be identified as objects of accounting. This is due to the fact that they are forecasted resources that are not quantified, and which are assumed to be based on geological prerequisites and (or) analogies with known deposits, that is, they are hypothetical in nature. It should be noted that, unlike minerals, mineral resources (mineral reserves) are clearly identified. Thus, the exploration and evaluation of mineral resources are carried out by a subsoil user at a specific field, that is, a subsoil area obtained on the basis of the right to use subsoil. That is, each field has individual characteristics (in the form of documentary information), distinguishing it from other objects with its own physical and legal parameters. These signs are recorded in the passports of deposits and manifestations of minerals created for maintaining the state cadaster of mineral resources. For each mineral deposit there should be information describing the location (region, district, coordinates, absolute elevation above sea level, name of the nearest station, pier, settlement indicating the distance to the deposit and direction), quality and quantity of the main mineral and minerals, together with him occurring with assignment of cadastral number (On approval of the Regulation, 2014).

The presence of clearly identified signs of mineral resources (mineral reserves) suggests the possibility of their consideration as objects of accounting. Let's consider this hypothesis.

Mineral resources (mineral reserves) can be an asset of the organization if they meet the relevant criteria for asset recognizing. 
S. Vegera, A. Malei, O. Romanova, V. Sushko. Environmental Innovation as a Part of Mineral Resources Accounting and Financial Reporting Development for Natural Capital Involvement in Management Decision-Making Process

According to the Conceptual Basis of Financial Reporting, an asset is understood as "resources controlled by an organization as a result of past events that are expected to bring future economic benefits to the organization" (The conceptual framework of financial reporting, 2018). It is separately stated that an object that meets the definition of an element may be recognized in the balance sheet if:

1. Admission to the organization or disposal of future economic benefits associated with this object seems likely.

2. The object has an initial value or value that can be reliably estimated" (The conceptual framework of financial reporting, 2018).

Thus, it is possible to single out the following criteria, the simultaneous fulfilment of which is mandatory for the recognition of mineral resources as an asset:

1. Control over the asset.

2. Occurrence as a result of past events.

3. The expectation of an increase in economic benefits, which is likely.

4. Availability of the initial cost or value that can be reliably assessed.

Consider the application of the first criterion: the presence of control over mineral resources. It should be noted that in most countries mineral rights belong to the state. Only in the USA are they mostly privately owned, although the government and other government agencies may be copyright holders. At the same time, in the United States between oil and gas companies and the owner of mineral rights, agreements are made (lease, concession, production sharing agreement, the service contract with risk), according to which the former receives a control function over mineral reserves under certain conditions.

To determine the presence of control over mineral resources from mining companies, it is necessary to determine who and in what amounts belong to the powers on the mineral reserves used. As a tool for solving these issues, a type of contract is used, according to which the rights to develop and extract mineral resources are transferred to the organization.

The authors considered the most widely used types of contracts in international practice: a lease agreement, a concession agreement, a production sharing agreement, a service contract with risk, and also their features in connection with oil and gas operations (R. A. Gallan, S. Wright, 2007). Each of these contracts provides for a share of active participation, according to which organizations obtain the rights to the discovered mineral reserves, and also cover the costs incurred for the exploration and development of the field. Thus, the existence of the right to control mining organizations for mineral resources is confirmed by the relevant legal agreements, since the organization, regardless of the ownership of the field, controls the benefits that are expected from the extraction of such mineral resources.

At the same time, the emphasis on the legal component in this case does not contradict the requirement of content priority over the form that the Conceptual Basis of Financial Reporting contains, as well as the national standards of the Republic of Belarus, the Russian Federation, Ukraine, Moldova, Kazakhstan, since mineral resources are necessary material prerequisite for mining industry and important means of production. The absence in the mining companies balance of the mineral resources of the developed field distorts information about the resource and economic potential of such organization.

Let's consider the second criterion, which is necessary for the recognition of mineral assets in the accounting system: the occurrence as a result of past events. "The assets of the organization arise from past operations or other past events. Organizations usually receive assets by acquiring or producing them, but other operations or events can also create assets" (The conceptual framework of financial reporting, 2018). The example of such other operations may be the development of mineral deposits.

As noted earlier, as a result of preliminary exploration, minerals are identified, and after geological exploration, minerals are transformed into mineral resources (mineral reserves), the use of which is proved on the basis of a quantitative assessment. Therefore, the presence of the second criterion for mineral resources is confirmed. 
S. Vegera, A. Malei, O. Romanova, V. Sushko. Environmental Innovation as a Part of Mineral Resources Accounting and Financial Reporting Development for Natural Capital Involvement in Management Decision-Making Process

The third criterion: the expectation of increased economic benefits, which is likely. Let's consider its' compliance with respect to mineral resources.

Mineral resources (mineral reserves) are a specific object that may have a wide range (from minimum to maximum value) of diverse characteristics that affect the probability of obtaining economic benefits: the degree of readiness for exploitation; the degree of reliability of determination, the degree of geological characteristics of occurrence conditions, the degree of technical feasibility of extraction from subsoil, etc.

In this regard, the existing classification systems operating in the Republic of Belarus, the Russian Federation, the United States, the United Kingdom, as well as those used in the global oil and gas industry were reviewed. According to the results of the study, it was revealed that at the moment each of the existing classifications of mineral resources separates them from the position of only one classification feature, which does not allow to fully identify those mineral resources that are expected to receive economic benefits and which, accordingly, can as an object of accounting.

Thus, it is necessary to develop a clear classification framework for the identification of mineral resources in the system of accounting and reporting of subsoil users.

In our opinion, given the diversity of characteristics of mineral resources that affect the likelihood of obtaining economic benefits, the United Nations Framework Classification for Fossil Energy and Mineral Resources and Resources 2009, which classifies mineral resources most fully, represents the classification framework for reflecting mineral resources in the accounts of business entities. simultaneously based on three fundamental criteria. The advantage of the UN Framework Classification is the possibility of its application on the basis of other terminology for obtaining comparable assessments (United Nations Framework Classification, 2010).

Based on this, three-dimensional classification of mineral resources was developed based on the UN classification of fossil energy and mineral reserves and resources for identification of accounting objects in the totality of mineral resources of the developed field, based on three criteria:

- availability of extraction (D1, D2);

- geological repute (A, B, C1, C2);

- economic practicability (R1, R2, R3).

Thus, according to the criterion of availability of extraction, mineral resources can be divided into accessible and inaccessible. According to the degree of geological study, they identify explored in detail (A), preliminary explored (B), poorly explored (C1) and previously estimated (C2) mineral resources. According to the economic practicability of mining, the aggregate of mineral resources based on the existing classifications can be divided into the following categories: profitable, conditionally profitable and unprofitable. Based on the principle of diligence, it is advisable to include in the list of accounting objects only those mineral resources that correspond to categories $A, B, C 1$. This position is explained by the fact that the reserves of these categories directly belong to proven deposits and, accordingly, form industrial mineral resources.

One of the conditions for the allocation of mineral resources (mineral reserves) in the composition of the assets of the organization is the validity of economically effective and expedient mining. In this connection, according to the criterion "economic practicability", only profitable ones will be included in the composition of mineral resources as accounting objects. However, not all proven and profitable reserves may be involved in using. So, there are a number of reasons why proven and profitable reserves cannot be extracted from the subsoil, namely: if they are located within water protection zones, sanitary protection zones of natural objects, territories of settlements, specially protected natural territories; if they do not allow the mining and geological conditions of occurrence; and many others. Consequently, for the purpose of reflecting in accounting and reporting of organizations of subsoil users, only available proven mineral resources available for extraction will be of particular interest. Thus, according to the authors, the part of mineral resources that simultaneously corresponds to the following features should be reflected in the 
S. Vegera, A. Malei, O. Romanova, V. Sushko. Environmental Innovation as a Part of Mineral Resources Accounting and Financial Reporting Development for Natural Capital Involvement in Management Decision-Making Process

statements of business entities: 1) explored in the number of categories $A+B+C 1$; 2 ) profitable; 3 ) available for extraction. The proposed three-dimensional classification of mineral resources and their composition as accounting objects is presented in Figure 2.
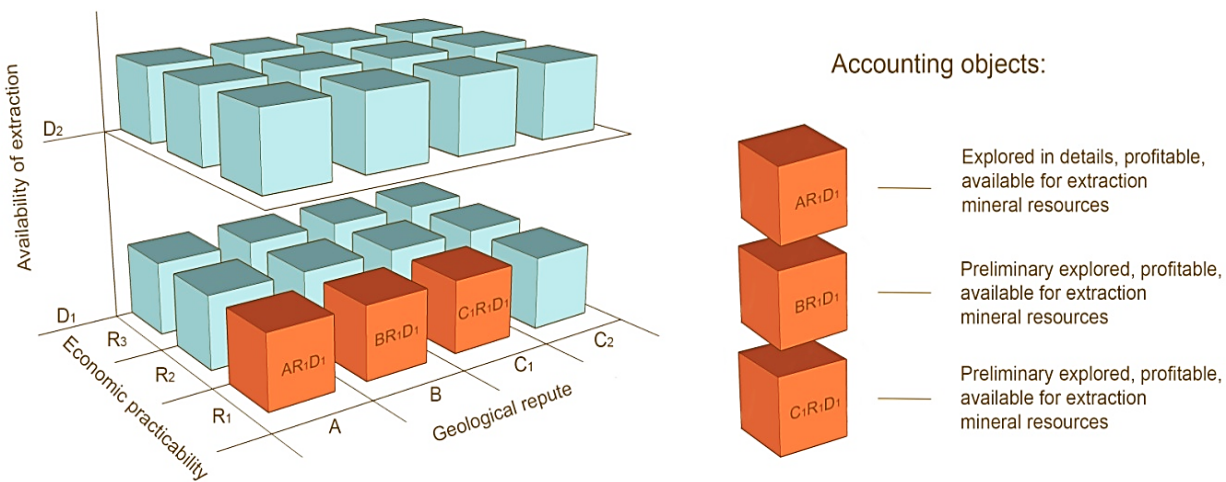

Figure 2-The proposed three-dimensional classification of mineral resources and their composition as objects of accounting

Sources: authors' development based on the study of special literature.

The proposed classification framework makes it possible to identify from the entire set of a field under development those reserves from which economic benefits are expected, which corresponds to the fourth criterion selected: the expectation of an increase in economic benefits that is likely.

We next consider the last criterion, the fulfilment of which is necessary for the recognition of mineral assets in the accounting system: the existence of an initial value or value that can be reliably estimated.

At the end of the 20th and the beginning of the 21st centuries, the world economy of mineral raw materials entered a new phase of its development, which is characterized by the following external factors: the emergence of a fundamentally new phenomenon in the world economy - the market of mineral resources bases (SME); the intensification of the processes of globalization of commodity markets, accompanied by the desire of developed countries to a balanced development and, as a result, the intensification of the struggle for their submission under their control (Development strategy of the geological industry, 2013). Consequently, the global market for an asset such as mineral resources is highly liquid, and its current market value can be assessed by obtaining information on past similar transactions, which can be considered a reliable assessment of mineral resources. Thus, the fourth criterion is also observed.

As a result of the study, our hypothesis about the possibility of recognizing mineral resources (mineral reserves) as assets in accounting and financial reporting system of organizations-subsoil users on the basis of clearly identified signs was confirmed. We have proven that mineral resources can be recognized as accounting objects subject to the simultaneous observance of the following criteria: 1) controlled, on the basis of a relevant agreement, giving the right to the organization-subsoil user of revenues from the use of the deposit; 2) in that part in which obtaining economic benefits from the use of mineral resources is probable, namely, explored (in the sum of categories $A+B+C 1$ ), profitable, available for extraction.

Evaluation and accounting of mineral resources as part of natural capital. The next significant issue, as well as one of the conditions for the recognition of mineral resources in the composition of accounting objects and reporting, as well as for reliable analysis of the activities of mining organizations is the assessment of mineral resources. 
S. Vegera, A. Malei, O. Romanova, V. Sushko. Environmental Innovation as a Part of Mineral Resources Accounting and Financial Reporting Development for Natural Capital Involvement in Management Decision-Making Process

In their work, S. Wright and R. Gallan noted that the true value of an oil and gas company is the value of its reserves, which can be fairly attributed to each extractive enterprise (R. A. Gallan, S. Wright, 2007).

The head of Lukoil, a large Russian oil producing company, V. Alekperov, notes that in order to increase the competitiveness of oil companies on world markets, "it is important to achieve a fair assessment (revaluation) of the cost of their capital through the valuation of oil and gas reserves. Now there is a repeated underestimation of these stocks" (Alekperov, V. Yu., 2013).

Evaluation of mineral resources is also necessary to determine the economic practicability of exploration, the most effective and safe ways to develop a field, regulate economic interests in the field of subsoil use and ensure the rational use of mineral potential.

The need for valuation of mineral resources as one of the most important tools for effective management of oil and gas and mining organizations is confirmed by the development and adoption of the International Guidelines "Assessing the Value of Assets in Extractive Industries" under the International Valuation Standards and the inclusion of the IFRS 6 "Exploration and mineral reserves assessment" in the composition of International Financial Reporting Standards. At the same time, it should be noted that despite the stated purpose of IFRS 6 "Exploration and appraisal of mineral resources" - defining the procedure for recording exploration and appraisal of mineral reserves in financial statements, this standard addresses the issues of recognition, assessment and disclosure only in relation to the costs incurred in the exploration and evaluation of mineral resources (IFRS 6, 2005).

To solve the problem of valuation of mineral resources as objects of accounting, long-term assets were evaluated, in particular, fixed assets according to IFRS requirements, as well as the legislation of the Republic of Belarus, the Russian Federation, Ukraine, Moldova and other countries.

In accordance with IAS 16 "Fixed assets", an item of fixed assets is initially valued at cost. For the subsequent accounting of fixed assets (IAS) 16 "Fixed assets" offers two models, giving business entities the right to choose in accounting policy one of the methods of subsequent accounting of fixed assets that are required to be applied to the entire class of fixed assets:

1. At actual costs: when an annual check of fixed assets for impairment is made (comparison with the market value) and in the presence of such an impairment, the residual value of the fixed asset will be reduced to its market value, and in the absence of depreciation the fixed asset will continue to be listed at historical cost (IAS 16, 2014). This method of subsequent accounting of fixed assets is focused on the principle of diligence.

2. At revalued cost: when to make an annual revaluation of the residual value of fixed assets to their market value (both in the case of its increase and in the case of its decrease) (IAS 16, 2014). This method of subsequent accounting of fixed assets allows evaluating the assets of the organization in the existing market conditions in terms of their resale.

Moreover, the method of subsequent accounting selected and fixed in accounting policies, and accordingly, estimates for different classes of fixed assets may be different. Thus, in OFP, in accordance with the requirements of (IAS) 16 "Fixed Assets", within one article, objects that are estimated both at actual costs and at current market prices are reflected simultaneously. In the Republic of Belarus (Resolution №26, 2012) and the Russian Federation (Provision on accounting "Accounting of Fixed Assets", 2001), investments in environmental facilities are recorded as fixed assets, which, after the object is accepted for accounting, can be recorded either at historical cost, if the revaluation is not mandatory in accordance with the legislation, or at a revalued cost.

At the same time, according to the legislation of the Republic of Belarus, revaluation can be carried out by three methods (the choice of one of these methods when conducting a revaluation of an organization's property is carried out independently for each property object):

1. The method of direct assessment based on the level of a new similar property. Thus, the revalued value represents the current market value of the object. 
S. Vegera, A. Malei, O. Romanova, V. Sushko. Environmental Innovation as a Part of Mineral Resources Accounting and Financial Reporting Development for Natural Capital Involvement in Management Decision-Making Process

2. The method of recalculating the currency value. The value of the object is converted into Belarusian rubles at the rate of the National Bank of the Republic of Belarus as of December 31 of the reporting year. Thus, the revalued cost represents the acquisition cost, adjusted for inflation.

3. Index. When carrying out the revaluation of fixed assets by the index method, the coefficients of change in the value of the types and groups of fixed assets, construction and installation, commissioning, other works and costs as of January 1 of the year following the reporting period are applied to their initial value recorded in accounting records before the revaluation. published by the National Statistical Committee of the Republic of Belarus, the Ministry of Architecture and Construction of the Republic of Belarus in the media of the Republic of Belarus (Resolution №162/131/37, 2010).

Guidelines for the accounting of fixed assets of the Russian Federation provide for the use of the index method or the direct method of revaluation at confirmed market prices (Order №91n, 2003). At the same time, land plots and objects of environmental management (water, subsoil and other natural resources) can also be revalued, since the ban on their revaluation was cancelled from January 1,2011 , by order of the Ministry of Finance of the Russian Federation of December 24, 2010, No. 186n.

In other words, in the balance sheet of organizations of the Republic of Belarus and the Russian Federation, the item "Fixed assets" also reflects objects estimated at actual costs as well as at current market prices. Despite the fact that in some countries, for example, the Republic of Moldova (On approval of the General chart of accounts, 2013), Ukraine (Instructions for the application of the chart of accounts, 1999), mineral resources are taken into account as independent objects in the "Mineral Resources", "Mineral Resources", and "Natural Resources" accounts, but there are still actual costs. on the involvement of mineral reserves in economic activity, and revaluation is allowed.

The analysis showed that at present, in the accounting of mining organizations, firstly, only actual expenses for the involvement of minerals in economic activities capitalized in fixed assets are reflected. However, these costs may subsequently be subject to revaluation at current market prices. As a result, the information on the cost of attracting mineral resources to economic activity is distorted to analyse the effectiveness of investment. Secondly, there is no accounting data on the economic value of the mineral resources controlled by the organization, which leads to a decrease in the informational value of the reporting and does not allow to evaluate the resource potential and investment attractiveness of the organization. The existing problems of the valuation of accounting objects and the relevance of the information received for different groups of users were pointed out in their writings by M. F. Van Breda, N. N. Karzayeva, M. I. Cooter, J. Richard, M. L. Pyatov, I. V. Sokolov, E. S. Hendriksen and others.

Valuation of assets at fair value is a principle of the static theory of balance. This is due to the fact that the purpose of static accounting is to determine whether the sale (sale) of all assets will allow an entrepreneur to currently receive the amount necessary to pay his accounts payable (J. Richard, 2000). Thus, the static balance sheet was intended to assess the property status of the company, analysis of possible bankruptcies (J. Richard, 2000). The approach to valuation of assets at fair value involves the revaluation, recognition and registration of all changes in value based on reliable data on the value of the disposal or the amount of cash expected to receive the asset (Kuter, M. I., 2008, Hendriksen, E. S., 2000). The main purpose of dynamic accounting is to measure, continuously or at close intervals, the efficiency of economic activity. In order to periodically assess the return on assets, it is necessary, unlike the static concept, to take into account the invested funds according to their cost to determine the mass of invested capital, which gave rise to one or another amount of profit. This necessarily implies the preservation of the originally set estimate, which may be the purchase price (equipment, raw materials), production cost (production), operating cost (rent of any equipment) (J. Richard, 2000). About the possibility of using in this case the revaluation procedure of E.S. Hendriksen, MF Van Breda points out the following: "With a change in the value of a monetary unit, assets, like current profit, should be revalued in accordance with the purchase value of money" (Hendriksen, 2000). In our opinion, the mixing of two types of assessment 
S. Vegera, A. Malei, O. Romanova, V. Sushko. Environmental Innovation as a Part of Mineral Resources Accounting and Financial Reporting Development for Natural Capital Involvement in Management Decision-Making Process

leads to the distortion and reduction of the information value of indicators of accounting (financial) statements, the results of the analysis of economic activities and complicates their interpretation. But at the same time, we note that both approaches to the assessment of resources are significant, as they provide an information base for various areas of analysis.

Thus, to take into account the relationship between the indicators of natural resource use and the organization's performance indicators, we propose a DUAL model for reflecting mineral resources in accounting (financial) statements, which allows us to provide information on natural capital to interested users in two aspects: the cost of attracting mineral resources (actual costs) and the economic potential of the mineral resources used (current market value), which provides an information base for relevant areas of analysis. At the same time, we suggest organizing accounting of the attracting mineral resources cost to the activities of business entities as follows:

1. Capitalize the costs of acquiring land plots, land rights, subsoil use rights and mineral reserves in the accounts of "Investments in long-term assets", "Fixed assets" or "Intangible assets", respectively. In the balance sheet, the source of assets at the actual cost of attracting mineral resources will be either equity capital or liabilities.

2. To re-evaluate these capitalized costs in connection with the change in the value of the monetary unit with the allocation to the account "Additional capital".

3. To carry out the depreciation of the specified capitalized costs in accordance with the legislation and the depreciation policy of the business entity with the allocation to the appropriate expense accounts.

4. In the analytical accounting and disclosure of information to reflect the resources owned by the organization and on limited real rights (rent, right to use and so on).

Due to the fact that at present in accounting and reporting of mining organizations the economic value of controlled mineral resources is not reflected, we suggest a method of their accounting, for the application of which we consider it necessary to open separate synthetic accounts Mineral Resources, Attracted Natural Capital, Depletion of mineral resources (Vegera, S.G., Metla, O.S., 2015). So, for reflection in the accounting and reporting of the economic potential of the mineral resources used at the current market value, we suggest using a separate synthetic account XX "Mineral Resources". The account model XX "Mineral Resources" is presented in Table 1.

Table 1 - Account model XX "Mineral resources"

\begin{tabular}{|l|l|}
\hline \multicolumn{1}{|c|}{ DX "Mineral resources" } \\
\hline \multicolumn{1}{|c|}{ Debit } & Credit \\
\hline $\begin{array}{l}\text { Initial balance - the current market value of mineral resources } \\
\text { at the beginning of the reporting period }\end{array}$ & Credit turnover \\
\hline \multicolumn{1}{|c|}{ Debit turnover } & \\
\hline \multicolumn{2}{|c|}{ Within a month } \\
\hline increase in the value of mineral resources after exploration & reducing the cost of mineral resources after mining \\
\hline $\begin{array}{l}\text { End balance - the current market value of mineral resources } \\
\text { at the end of the reporting period }\end{array}$ & \\
\hline
\end{tabular}

Sources: authors' development in the framework of the proposed method of accounting for mineral resources

As noted earlier, one of the criteria for reflecting mineral resources as part of an organization's assets assumes control over the reserves used. At the same time, this control right can be established on the basis of a relevant agreement entitling the subsoil user to the proceeds from the use of the field. Consequently, in accounting records of subsoil users on account XX of the "Mineral Resources" account should be reflected at fair value only that part of mineral resources to which, according to the terms of the 
S. Vegera, A. Malei, O. Romanova, V. Sushko. Environmental Innovation as a Part of Mineral Resources Accounting and Financial Reporting Development for Natural Capital Involvement in Management Decision-Making Process

contract and in accordance with the share of active participation, they have rights. As noted above, IFRS 13 Fair Value Measurement treats the fair value as the price that would be received if an asset was sold or paid to transfer a liability when a transaction was conducted on a voluntary basis between market participants at the valuation date in current market conditions (IFRS 13, 2013).

The principle of fair valuation provides for revaluations (impairment) of assets, since during the time that the organization owns the assets, the initial valuation may change significantly from their value at the time of reporting the data to users. In our opinion, for subsequent accounting of mineral resources, it is necessary to apply only a model at a revalued value and reassessment should be carried out both due to changes in the fair value of mineral resources and when reserves change based on exploration results. Moreover, this may be not only an increase in the initial cost of mineral resources but also their depreciation, for example, if, according to the results of the additional exploration, the reserves will be reduced to the lower side. The source of assets reflecting the economic potential of the mineral resources used in the assessment at the current market value seems reasonable to consider natural capital. Investigating the problems of capital property accounting, A. P. Shevlyukov points out: "State-owned land organizations and natural resources are received for use free of charge, in connection with which they are invited to use the state-allocated value of natural capital as a source of financing" (A. P. Shevlyukov, 2009). For these purposes, they recommended the account "Natural Capital" (A. P. Shevlyukov, 2009). The inclusion of natural capital in the balance of the organization as a source of asset formation is proposed by Yu.V. Altukhova, V.G. Shirobokov (2010). In turn, S. G. Vegera (2011) suggested using the "Attracted Natural Capital" account to reflect in accounting records of the Republic of Belarus sources of land plots on the right of lease, permanent, temporary use in cadastral valuation, since these land plots are state-owned according to Belarusian legislation and only the implementation of their activities.

This clarification is also relevant for mineral resources, as, in most countries, mineral rights belong to the state. The mineral resources used are attracted by natural capital, which should be reflected in the name of the account and taken into account when analysing the financial condition of the organization. On this basis, in our opinion, attracted natural capital, which We offer to reflect on the same account XX "Attracted natural capital". Account model XX "Attracted natural capital" is presented below (Table 2).

Table 2 - Account model XX "Attracted natural capital"

\begin{tabular}{|c|l|}
\hline \multicolumn{4}{|c|}{ XX "Attracted natural capital" } \\
\hline Debit & \multicolumn{1}{c|}{ Credit } \\
\hline & $\begin{array}{l}\text { Initial balance }- \text { attracted natural capital } \\
\text { at the beginning of the reporting period }\end{array}$ \\
\hline Debit turnover & \multicolumn{1}{|c|}{ Credit turnover } \\
\hline & Within a month \\
\hline- the retirement of attracted natural capital & - attracted natural capital \\
\hline & $\begin{array}{l}\text { End balance }- \text { attracted natural capital } \\
\text { at the end of the reporting period }\end{array}$ \\
\hline
\end{tabular}

Sources: account model previously presented (Vegera, S.G., 2011)

The proposed account XX "Attracted Natural Capital" will summarize information about the amount of attracted natural capital after exploration and assessment of mineral resources. It should be noted that accounting system for mineral resources must not only general information to reflect the mineral reserves of subsoil users of the Republic of Belarus as part of national wealth but also include accounting for the depletion of mineral resources. This will provide the necessary information base for calculating macroeconomic indicators of the country's sustainable development, characterizing human progress, taking into account environmental and social factors, the relationship between environmental quality, 
S. Vegera, A. Malei, O. Romanova, V. Sushko. Environmental Innovation as a Part of Mineral Resources Accounting and Financial Reporting Development for Natural Capital Involvement in Management Decision-Making Process

depletion of natural resources and economic growth. Due to the fact that the indicator "depletion" is used to reflect the decrease in the value of mineral assets as a result of their extraction from the subsoil, we suggest accounting it in the accountant on the passive synthetic account XX "Depletion of mineral resources. Account model XX "Depletion of mineral resources" is presented in Table 3.

Table 3 - Account model XX "Depletion of mineral resources"

\begin{tabular}{|c|l|}
\hline \multicolumn{2}{|c|}{ XX "Depletion of mineral resources" } \\
\hline Debit & \multicolumn{1}{c|}{ Credit } \\
\hline & $\begin{array}{l}\text { Initial balance - the amount of depletion of mineral resources } \\
\text { beginning of the reporting period }\end{array}$ \\
\hline Debit turnover & \multicolumn{1}{|c|}{ Credit turnover } \\
\hline \multicolumn{1}{|c|}{ Within a month } \\
\hline write-off of depletion of mineral resources & $\begin{array}{l}\text { accrual of depletion of mineral resources as a result of mining from } \\
\text { the depths }\end{array}$ \\
\hline & $\begin{array}{l}\text { End balance - the amount of depletion of mineral resources at the } \\
\text { end of the reporting period }\end{array}$ \\
\hline
\end{tabular}

Sources: authors' development in the framework of the proposed method of accounting for mineral resources

Thus, the reflection in the accounting and reporting of the economic potential of the mineral resources used we propose to carry out as follows: reflect the current market value of the resource by the debit of the account "Mineral Resources" and the credit of the account "Attracted Natural Capital"; to reassess the current market value of the resource in connection with the change in the current market prices and the volume of reserves as a result of the additional exploration and to refer to the "Attracted Natural Capital"; the depletion of resources (mining) reflects using the account "Depletion of mineral resources"; in the analytical accounting and disclosure of information to reflect the resources owned by the organization and on limited real rights (rent, right to use and so on). We have recommended the following typical correspondence of accounts for the accounting of the economic potential of the mineral resources used (table 4).

Table 4 - Proposed correspondence for the accounts of the economic potential of the mineral resources used

\begin{tabular}{|c|c|c|}
\hline Contents of operation & Debit & Credit \\
\hline $\begin{array}{l}\text { Reflected the attraction of natural capital in the amount of the } \\
\text { current market value of mineral resources controlled by the } \\
\text { organization according to the terms of the contract }\end{array}$ & $\begin{array}{l}\text { XX "Mineral } \\
\text { resources" }\end{array}$ & $\begin{array}{l}\text { XX "Attracted natural } \\
\text { capital" }\end{array}$ \\
\hline $\begin{array}{l}\text { Reflected the depletion of attracted natural capital as a result of } \\
\text { the extraction of mineral resources }\end{array}$ & $\begin{array}{l}\text { XX "Attracted natural } \\
\text { capital" }\end{array}$ & $\begin{array}{l}\mathrm{XX} \text { «Depletion of } \\
\text { mineral resources» }\end{array}$ \\
\hline Charged previously reflected depletion of attracted natural capital & $\begin{array}{l}\mathrm{XX} \text { «Depletion of } \\
\text { mineral resources» }\end{array}$ & $\begin{array}{l}\text { XX "Mineral } \\
\text { resources" }\end{array}$ \\
\hline Reflected the reassessment of the value of mineral resources & $\begin{array}{l}\text { XX "Mineral } \\
\text { resources" }\end{array}$ & $\begin{array}{l}\text { XX "Attracted natural } \\
\text { capital" }\end{array}$ \\
\hline Reflected the devaluation of the value of mineral resources & $\begin{array}{l}\text { XX "Attracted natural } \\
\text { capital" }\end{array}$ & $\begin{array}{l}\text { XX "Mineral } \\
\text { resources" }\end{array}$ \\
\hline $\begin{array}{l}\text { Reflects the retirement of attracted natural capital at the current } \\
\text { market value of mineral resources controlled by the organization } \\
\text { according to the terms of the contract }\end{array}$ & $\begin{array}{l}\text { XX "Attracted natural } \\
\text { capital" }\end{array}$ & $\begin{array}{l}\text { XX "Mineral } \\
\text { resources" }\end{array}$ \\
\hline
\end{tabular}

Sources: authors' development 
S. Vegera, A. Malei, O. Romanova, V. Sushko. Environmental Innovation as a Part of Mineral Resources Accounting and Financial Reporting Development for Natural Capital Involvement in Management Decision-Making Process

The proposed methodology will allow assessing the property, resource potential and investment attractiveness of the mining organizations. The proposed model for the reflection of information on mineral resources in accounting and reporting of organizations - subsoil users of the Republic of Belarus, in accordance with which accounting of all used mineral resources is organized, divided into own and not own in two estimates: based on actual costs of resource acquisition and at current market value, in table 5 .

Table 5 - The proposed model of reflection of information on mineral resources in the accounting and reporting of organizations - subsoil users of the Republic of Belarus

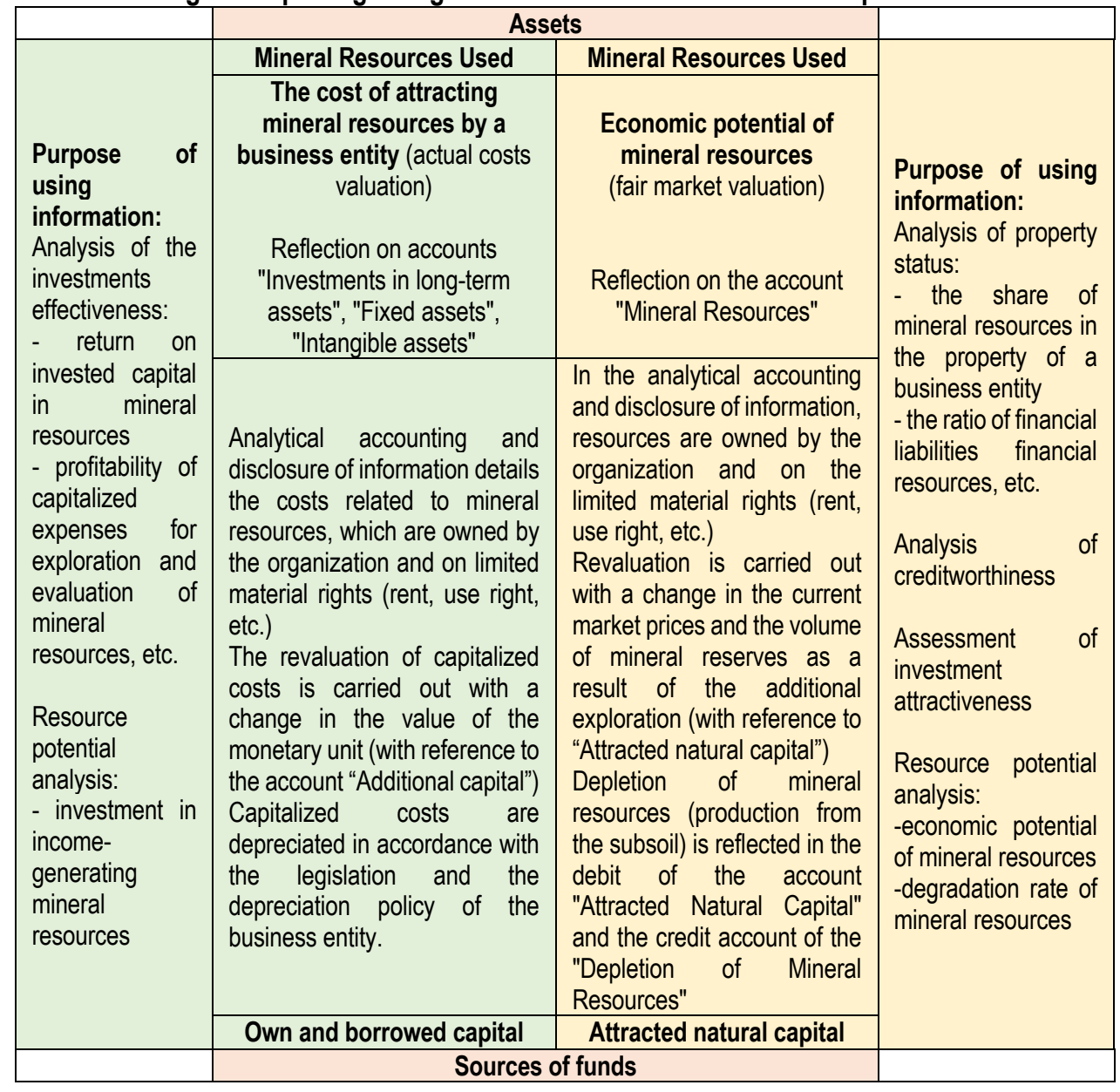

Sources: authors' development

The use of this model will eliminate the distortions of the information provided, ensure interconnection of indicators of natural resource use and indicators of the organization's activities, as well as form the basis for various users of accounting (financial) reporting in the areas of analysis that interest them, which increases the information value of the reporting and its forecast characteristics.

Improving the information content of accounting (financial) statements of organizations-subsoil users. 
S. Vegera, A. Malei, O. Romanova, V. Sushko. Environmental Innovation as a Part of Mineral Resources Accounting and Financial Reporting Development for Natural Capital Involvement in Management Decision-Making Process

Currently, completeness, availability and content of disclosed information in accounting (financial) statements of oil-gas and mining organizations do not meet the requirements of effective management of rational subsoil use.

As noted earlier, the most important asset of mining organizations are mineral resources, and information on the volume and value of these reserves is not reflected in accounting (financial) statements. Consequently, there are no data on the availability of attracted natural capital in the activities of the organization.

In addition, there is no other information reflecting the specifics of the activities of the extractive industry organizations necessary for analysing the environmental aspects of subsoil use, namely, there are no data on changes in the volume and value of mineral resources as a result of their depletion, additional exploration or revaluation.

These circumstances make it difficult to collect and process the necessary information for indicators of analysing the use of mineral resources, which leads to certain difficulties in making management decisions on geological exploration, assessment of strategic and operational risks in conditions of depletion of mineral resources, reduces competitiveness and ultimately affects the market value organization and its development prospects.

In this regard, based on the previously substantiated need for accounting and reflecting in accounting (financial) statements the value of mineral resources as part of natural capital, we suggest that for subsoil users' organizations to make appropriate changes to accounting (financial) reporting forms.

It should be noted that the issues under consideration have been discussed for many years by the developers of standards for financial accounting in international oil and gas companies. Thus, in 1982, SFAS No. 69 "Disclosure of information on oil and gas production" was issued, intended for companies using US GAAP. This standard requires disclosure of the method used to account for the exploration and production of hydrocarbons, as well as related capital expenditures. In addition, companies must publish information about the volume and value of stocks (Statement of financial accounting standards № 69,1982 ).

Detailed disclosure of information prescribes and SORP 2001 "Accounting activities for the exploration, development, production and disposal of oil and gas assets" (Statement of recommended practice, 2001). The provisions contained in the 2001 SORP are similar to SFAS №69, with the exception of the mandatory publication of inventory value data.

In accordance with SFAS №69, it is necessary to provide information in connection with changes in the volume of proven reserves of oil and gas that occurred during the year. Changes may be due to the following factors: revision of previous estimates; increased oil recovery; the purchase of subsurface sites containing hydrocarbons; expansion of areas and discoveries; prey; the sale of subsurface sites containing hydrocarbons (Statement of financial accounting standards № 69, 1982).

The disclosure of the listed data represents the necessary information not only for analysing the feasibility of developing the field but also for the investor in assessing the effectiveness of the organization of the mining industry.

In November 2000, the Council for International Financial Reporting Standards published a collection of documents, which set forth questions on the main issues related to the development of a standard for the extractive industry. In particular, it raised the question of the appropriateness of disclosing information about the volume and value of stocks (Wright, Ch. D., 2007).

At the same time, the issue of disclosing information on mineral reserves in accounting (financial) statements is currently being discussed by the Board of the International Accounting Standards Board in the discussion paper "Mining". This document contains proposals for the disclosure of the following information, which will be included in the requirements for the set of financial statements and, therefore, will be included in the scope of the audit report: the volume of reserves by type of commodity, by country 
S. Vegera, A. Malei, O. Romanova, V. Sushko. Environmental Innovation as a Part of Mineral Resources Accounting and Financial Reporting Development for Natural Capital Involvement in Management Decision-Making Process

or project; assessment of the current or fair value of proved and probable reserves by major geographic regions; revenue from mining activities by type of raw materials; costs (Prospects for the development of accounting, 2010).

Given these comments, it is highly likely that the new international standard for extractive industry organizations will require disclosure of information on the level of reserves.

Thus, on the basis of the above, we propose in the balance sheet the current market value of the mineral resources used to be shown as follows:

- as part of the organization's long-term assets in the line "Mineral Resources";

- in the sources of their formation - as part of the equity in the line "Attracted natural capital".

Reflection on the balance sheet of the value of mineral resources allows you to generate reliable information for making management decisions on current and investment activities.

Reflection in the composition of the equity capital of the organization of the mining industry attracted natural capital leads to the need to make changes in the report on changes in equity capital. We suggest supplementing the current form of the report with the column "Attracted Natural Capital", the lines of which will reflect the corresponding changes.

As noted earlier, the exploration and evaluation of mineral resources have a number of distinctive features. Not all information reflecting the specifics of this activity is reflected in accounting (financial) reporting forms, but at the same time it requires mandatory disclosure according to SFAS No. 69 "Disclosure of information on oil and gas production" and SORP 2001 "Accounting for exploration activities, development, extraction and disposal of oil and gas assets".

In this regard, we offer information regarding the specifics of the extractive organizations and affecting the assessment of the effectiveness of their activities, to disclose in the notes to the statements.

Due to the fact that the balance sheet of the proposed line "Mineral Resources" will reflect the fair value of mineral resources used minus their depletion, we suggest disclosing the value of mineral resources depletion for the reporting period in the notes to the statements.

The balance sheet provides for the reflection of information only in the valuation. In other words, data on total mineral reserves, as well as in the context of various categories, are not available to interested users. As noted earlier in the reporting of business entities, the part of mineral resources that simultaneously corresponds to the following features should be reflected: 1) explored (in the sum of categories $A+B+C 1$ ); 2) profitable; 3 ) available for extraction. Therefore, in the notes to the statements, it is advisable to reflect the number of estimated mineral reserves for each of these specified categories separately. According to the proposed method of accounting for the economic potential of the mineral resources used, it is necessary for subsequent accounting of mineral resources, it is necessary to apply only the model at a revalued cost and reassess the value of mineral resources (mineral reserves) both in connection with changes in their fair value and when the reserves change additional exploration. Based on this, we propose in the notes to the statements to disclose the relevant reason for the revaluation of the fair value of mineral resources.

The lack of analytical data on the detailed structure and conditions for changes in the volume of mineral resources makes it difficult to assess and manage the efficiency of geological exploration, re-evaluation and more. There is a need to provide explanations to information about the volume of stocks and the reasons for their changes. Summarizing the above, let us present recommendations on improving the forms of accounting (financial) reporting of organizations-subsoil users of the Republic of Belarus in table 6.

Disclosure of the proposed information in the balance sheet, statement of changes in equity, notes to the statements will allow subsoil users to expand the information base for analysing the use of mineral resources, improve the quality of information provided, which is the basis for making decisions in the field of rational use of mineral resources. 
S. Vegera, A. Malei, O. Romanova, V. Sushko. Environmental Innovation as a Part of Mineral Resources Accounting and Financial Reporting Development for Natural Capital Involvement in Management Decision-Making Process

Table 6 - Recommendations for improving the forms of accounting (financial) statements of organizations-subsoil users of the Republic of Belarus

\begin{tabular}{|c|c|}
\hline Report Title & Suggestions \\
\hline Balance sheet & $\begin{array}{l}\text { Section I. Long-term assets } \\
-\quad \text { mineral resources; } \\
\text { Section III. Equity } \\
\quad-\quad \text { attracted natural capital }\end{array}$ \\
\hline Report on changes in equity & Attracted natural capital \\
\hline Notes & 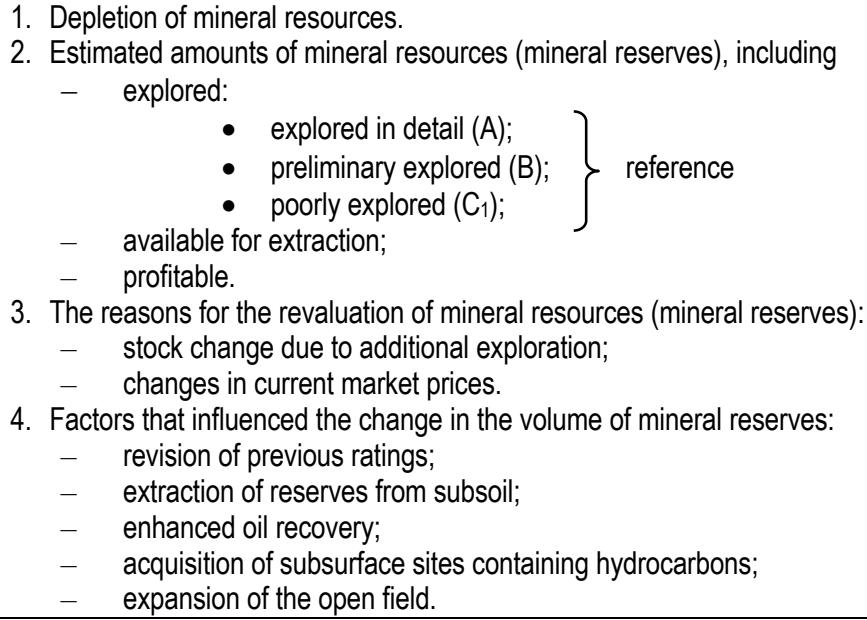 \\
\hline
\end{tabular}

Sources: authors' development

Conclusions. As a part of environmental innovation implementation, natural capital involvement into the making management decisions of subsoil users' organizations by reflecting information on mineral reserves in accounting and reporting system, the economic essence of the concepts of "minerals", "mineral reserves", "mineral resources" and "mineral raw materials" was conducted. The results of this study allowed to establish their identity / non-identity, correlate each category with the stage of the field life cycle and justify that only mineral resources (mineral reserves), which, unlike other categories, can be clearly identified by field, can be the object of accounting. quality and quantity. At the same time, mineral resources for their reflection in accounting and reporting system must meet the following criteria: controlled, on the basis of a relevant agreement, entitling the subsoil user to the income from the use of the field; in that part in which obtaining economic benefits from the use of mineral resources is probable, namely, explored (in the sum of categories $A+B+C 1$ ), profitable, available for extraction.

In the framework of studying the problem of the relationship of indicators of the use of natural capital and the economic results of a business entity, a study was conducted to assess the long-term natural resources used in IFRS, Belarus, the Russian Federation, Ukraine, and Moldova. As a result, it has been established that at present, in the accounting of mining organizations, firstly, only the actual costs of the involvement of minerals in economic activities capitalized in fixed assets are reflected. However, these costs may subsequently be subject to revaluation at fair value. As a result, the information on the cost of attracting mineral resources to economic activity is distorted to analyse the effectiveness of investment. Secondly, there is no accounting data on the economic value of the mineral resources controlled by the organization, which leads to a decrease in the informational value of the reporting and does not allow to evaluate the resource potential and investment attractiveness of the organization. 
S. Vegera, A. Malei, O. Romanova, V. Sushko. Environmental Innovation as a Part of Mineral Resources Accounting and Financial Reporting Development for Natural Capital Involvement in Management Decision-Making Process

To solve this problem, the issues of correlation of goals and types of resource assessment in static and dynamic balance theories were considered. Based on the conducted research, a new dual model of reflection of mineral resources in accounting (financial) statements was developed, which allows presenting information on natural capital to interested users in two aspects: the cost of attracting mineral resources (actual costs) and the economic potential of the mineral resources used (current market value), which provides an information base for relevant areas of analysis. The use of this model will eliminate the distortions of the information provided, ensure the interrelation of indicators of natural resource use and indicators of the organization's activities, as well as form the basis for users of accounting (financial) reporting in areas of interest to them, which increases the information value of the reporting and its forecast characteristics. Due to the fact that current accounting and reporting of mining organizations do not reflect the economic value of controlled mineral resources, a method of their accounting has been developed, for which it was proposed to open separate synthetic accounts Mineral Resources, Attracted Natural Capital, Depletion mineral resources ". It is recommended that the debit of the "Mineral Resources" account and the "Attracted Natural Capital" account credit reflect the fair value of the part of the mineral reserves to which organizations have rights in accordance with the active participation share under the terms of the contract. The depletion of resources as a result of their extraction from the depths has been proposed to be reflected using the "Depletion of Mineral Resources" account. Revaluation is recommended to carry out when current market prices and volumes of reserves change according to the results of additional exploration and to be referred to "Attracted Natural Capital". The proposed method will allow evaluating the property, resource potential and investment attractiveness of mining organizations.

The justified need to account for and reflect in accounting (financial) statements the value of mineral resources as part of natural capital necessitated a change in the forms of accounting (financial) statements for subsoil users. In this regard, recommendations for improving the forms of accounting (financial) statements based on the proposed method of accounting for mineral resources have been developed. In the balance sheet in the composition of long-term assets in the line "Mineral resources" it is recommended to reflect the fair value of the mineral resources used, and the sources of their formation - inequity in the line "Attracted natural capital". It is proposed to supplement the form of the report on changes in equity with the column "Attracted Natural Capital". In the notes to the statements recommended posting information revealing the specifics of the extractive industry: data on the volume of mineral reserves; factors affecting their change; reasons for revaluation of mineral resources.

Thus, the proposed economic nature and composition of mineral resources as objects of accounting, the method of accounting for the economic value of controlled mineral resources, recommendations for improving accounting (financial) statements, providing information about the organization's natural capital and its depletion, are of particular importance from the perspective of long-term development for organizations of subsoil users, and for environmental management in the global community.

\section{References}

The depletion of natural capital will be one of the most acute problems of business in the XXI century. (2014, June 18). Retrieved from: http://www.pr-release.ru/cat/news/49647.

Mass demonstration of support for measures to account for natural capital at the Rio Summit. (2012, June 20). Retrieved from: http://www.worldbank.org/en/news/press-release/2012/06/20/massive-show-support-action-natural-capital-accounting-rio-summit

On approval of the National Security Concept of the Republic of Belarus. (2010, November 9). Retrieved from: http://www.pravo.by/document/?guid=3871\&p0=P31000575

Development strategy of the geological industry and intensification of the development of the mineral resource base of the

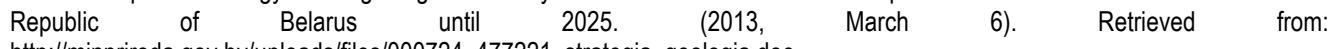
http://minpriroda.gov.by/uploads/files/000724_477221_strategia_geologia.doc .

Altukhova, Yu. V., Shirobokov, V. G. (2010). Accounting and analytical support for managing sustainable development of agricultural enterprises. Voronezh: Origins. 
S. Vegera, A. Malei, O. Romanova, V. Sushko. Environmental Innovation as a Part of Mineral Resources Accounting and Financial Reporting Development for Natural Capital Involvement in Management Decision-Making Process

Zamula, I. V. (2010). Accounting of environmental activities in ensuring sustainable development of the economy. Zhytomyr: State Tehnological University.

Richard, J. (2000). Accounting: Theory and Practice. France: Finance and Statistics.

Shevlyukov, A. P. (2009). Paradigms of the Russian model of capital property accounting. Gomel: Belarusian University of Trade and Economics Consumer Cooperation.

Wright, Ch. D. (2007). International Petroleum Accounting. Moscow: Olimp-business.

Johnston, D. (2005). Analysis of the economics of exploration, risks and agreements in the international oil and gas industry. Moscow: Olimp-business.

Mygkih, M. A. (2006). The need to fully account for the cost of exploration, development and operation of oil fields. Retrieved from: http://www.auditfin.com/fin/2006/5/Mygkih/Mygkih\%20.pdf.

Chaya, V. T. (2010). Features of accounting in oil and gas companies. Audit and financial analysis, 1, $59-82$.

Horngren, H. T. (1995). Accounting: management aspect. Moscow: Finance and Statistics.

Agoshkov, M. I. (1974). Techno-economic assessment of the extraction of minerals from the subsoil. Moscow: Nedra.

Dunaev, F. F. (1983). Economics of the oil and gas industry: studies. Moscow: Nedra.

Zyleva, N. V. (2015). About the possibilities of analyzing search costs based on indicators of external reporting. Bulletin of Omsk University. Series "Economy", 1, 24-29.

Ibragimova, A. Kh. (2012). Methodological aspects of cost accounting for exploration. Retrieved from: http://www.auditfin.com/fin/2012/1/2012_I_02_03.pdf.

Egorin, P. G. (1988). Economic analysis of the activities of geological organizations. Moscow: Nedra.

Popov, A. Yu. (2013). Peculiarities of accounting for search assets. News of the Ural State University of Economics, 5, 69-75. Unukovich, A.V. (2012) Geological and economic assessment of mineral deposits of Belarus. Minsk: Belarussian Science.

Tsalko, V. G. (2011). Nedra of Belarus - one of the main wealth of the country. Economy of Belarus, 2, 70-78.

Code of the Republic of Belarus on Subsoil. (2008, July 14). Retrieved from: http://kodeksy.by/kodeks-o-nedrah

Mining Law of Ukraine. (1999, October 6). Retrieved from: http://base.spinform.ru/show_doc.fwx?rgn=11212.

Sekisov, G. V. (1994) Mineral objects and their rational development. Moscow: Science.

On Subsoil and Subsoil Use. (2010, June 24). Retrieved from: http://base.spinform.ru/show_doc.fwx?rgn=31379.

Tax Code of the Russian Federation (Part Two). (2000, July 19). Retrieved from:

http://www.consultant.ru/document/cons_doc_LAW_28165/

Shimova, O. S. (2012) Environmental Economics: studies. Manual. Moscow: Infra-M.

Prokhorov, A. M. (1975). Minerals. Retrieved from: http://bse.sci-lib.com/article090698.html.

On approval of the Regulation on the procedure for maintaining the state cadastre of the subsoil of the Republic of Belarus.

(2014, January 1). Retrieved from: http://pravo.newsby.org/belarus/postanovsm12/sovm017.htm

The conceptual framework of financial reporting. (2018, March). Retrieved from: https://www.minfin.ru/common/upload/library/2014/06/main/kontseptualnye_osnovy_na_sayt.pdf

Overview of the main provisions of the revised System of National Accounts 1993 (2008 SNA) and proposals for their phased

application in the statistics of the CIS countries. (2008). Retrieved from: http://budgetrf.ru/stat/Publications/cis/sns08.pdf.

United Nations Framework Classification for Fossil Energy and Mineral Reserves and Resources. (2010). Retrieved from:

http://www.unece.org/fileadmin/DAM/energy/se/pdfs/UNFC/unfc2009/UNFC2009_ES39_r.pdf.

Alekperov, V. Yu. (2013). Oil potential. Retrieved from: http://www.lukoil.ru/press.asp?div_id=2\&year=2002\&id=349\&pr=yes.

International Financial Reporting Standard (IFRS) 6 "Exploration and evaluation of mineral reserves". (2005, June 30). Retrieved

from: http://allmsfo.ru/images/stories/Downloads/msfo/IFRS/ifrs06.pdf.

International Financial Reporting Standard (IAS) 16 "Fixed Assets". (2014, June 30). Retrieved from:

http://allmsfo.ru/images/stories/Downloads/msfo/lAS/ias16.pdf.

International Financial Reporting Standard (IFRS) 13 "Fair Value Measurement". (2013, December 12). Retrieved from: http://allmsfo.ru/images/stories/Downloads/msfo/IFRS/ifrs13.pdf.

Resolution of the Ministry of Finance of the Republic of Belarus №26 "Instructions for accounting of fixed assets". (2012, April

30). Retrieved from: http://www.bntu.by/images/stories/msf/econ/doc/uchet_osn_sr.pdf

Provision on accounting "Accounting of Fixed Assets". (2001, March 30). Retrieved from: $\mathrm{http}: / /$ www. consultant.ru/cons/cgi/online.cgi? $r$ req $=$ doc\&base $=$ LAW\&n $=199487 \&$ fld $=134 \& d s t=100011,0 \& \mathrm{rnd}=0.6808385398557937 \#$ 03557818765084544

Resolution of the Ministry of Economy of the Republic of Belarus, Ministry of Finance of the Republic of Belarus, Ministry of Architecture and Construction of the Republic of Belarus No. 162/131/37 "On the procedure for the revaluation of fixed assets not completed by the construction of facilities, non-installed equipment". (2010, November 5). Retrieved from: http://pravo.newsby.org/belarus/postanov5/pst173.htm

Order of the Ministry of Finance of the Russian Federation N 91n "On Approval of Guidelines for Accounting for Fixed Assets". (2003, October 13). Retrieved from: http://pravo.gov.ru/proxy/ips/?docview\&page=1\&print=1\&nd=102097221\&rdk=2\&\&empire= On
approval of the General chart of accounts. (2013, August 6). Retrieved from: http://www.mf.gov.md/files/files/Acte\%20Legislative\%20si\%20Normative/CONTABILITATE/ordine/Plan\%20de\%20conturi\%20.pdf. 
S. Vegera, A. Malei, O. Romanova, V. Sushko. Environmental Innovation as a Part of Mineral Resources Accounting and Financial Reporting Development for Natural Capital Involvement in Management Decision-Making Process

Instructions for the application of the chart of accounts for accounting of assets, capital, liabilities and business transactions of enterprises and organizations. (1999). Retrieved from: http://base.spinform.ru/show_doc.fwx?rgn=11650\#A0000000001.

Kuter, M. I. (2008). Accounting Theory: Studies. Moscow: Finance and Statistics.

Hendriksen, E. S. (2000). Accounting theory: studies. Moscow: Finance and Statistics.

Vegera, S.G., Metla, O.S. (2015). Assessment and accounting of mineral resources as part of natural capital: problems and solutions. Accounting and analysis, 9, 8-15.

Vegera, S.G. (2011). Development of land accounting methodology in the context of the modern theory of rent. Novopolotsk: Polotsk State University.

Statement of financial accounting standards № 69 «Disclosures about oil and gas producing activities an amendment of FASB statements 19, 25, 33 and 39». (1982, November). Retrieved from: $\mathrm{http}: / / w w w . f a s b . o r g / c s / B l o b S e r v e r ? b l o b c o l=u r l d a t a \& b l o b t a b l e=M u n g o B l o b s \& b l o b k e y=i d \& b l o b w h e r e=1175823287861$ \&blobheader $=$ application $\% 2 \mathrm{Fpdf}$.

Statement of recommended practice «Accounting for oil and gas exploration, development, production and decommissioning Activities». (2001, June 7). Retrieved from: http://oiac.co.uk/wp-content/uploads/2015/05/SORP.pdf.

Prospects for the development of accounting in the extractive industries? (2010, May). Retrieved from http://www.pwc.ru/ru_RU/RU/training/ifrs-us-gaap/bulletin/ifrs-newletter-may10.pdf.

C. Berepa, к.е.н., доцент, Полоцький державний університет (Республіка Білорусь);

O. Малей, к.е.н., доцент, Полоцький державний університет (Республіка Білорусь);

O. Романова, к.е.н., доцент, Полоцький державний університет (Республіка Білорусь);

B. Сушко, к.е.н., доцент, Полоцький державний університет (Республіка Білорусь)

Екологічні інновації як невід'ємна складова розвитку системи обліку мінеральних ресурсів: врахування природного капіталу при прийнятті управлінських рішень

У статті автори визначають необхідність врахування природного капіталу при прийнятті управлінських рішень у ході реформування існуючої системи бухгалтерського обліку та звітності мінеральних ресурсів. При цьому автори розглядають процес реформування існуючої системи обліку як екологічні інновації, що створюють передумови для використання нових моделей ведення бізнесу, які забезпечують зменшення екодеструктивного впливу на навколишне природне середовище та стимулюють раціональне використання природних ресурсів. На основні результатів дослідження автори визначають мінеральні ресурси як невід'ємну частину природного капіталу. При цьому в існуючій системі обліку та звітності підприємств (користувачів надр) дані про використання мінеральних ресурсів (як складової природного капіталу) відсутні, що тим самим підтверджує актуальність даного дослідження. Метою статтіє теоретичне обгрунтування рекомендацій щодо удосконалення методів обліку мінеральних ресурсів на підприємствах (користувачах надр) в контексті концепції природного капіталу. У рамках дослідження автори використовували наступні методи: синтез, аналіз, порівняння, логічне узагальнення, висновок за аналогією, класифікацію, групування, тощо. 3 метою виокремлення ідентичності / не ідентичності понять «мінерали», «запаси корисних копалин», «мінеральні ресурси» та «мінеральна сировина» автори систематизують підходи до ї визначення з точки зору формування інформаційної бази даних про використання мінеральних ресурсів в рамках розробки системи ї обліку. У статті запропоновано тривимірну класифікацію корисних копалин з точки зору прогнозованої економічноі вигоди від їх використання. Авторами доведено, що мінеральні ресурси можуть виступати об'єктом бухгалтерського обліку, оскільки вони мають усі необхідні характеристики, що притаманні активам підприємства. Так, авторами розроблено подвійну модель обліку мінеральних ресурсів (як складової природного капіталу) та їх відображення в бухгалтерських (фінансових) звітах підприємств, яка дозволяє представляти інформацію про природний капітал стейкхолдерам у двох аспектах: вартість залучення мінеральних ресурсів та економічного потенціалу ї використання, що дозволить усунути викривлення інформації у системі обліку та забезпечить інформаційну базу для подальших відповідних досліджень. У відповідності до мети дослідження автори розробили систему рекомендацій щодо вдосконалення системи бухгалтерських (фінансових) форм звітності підприємств (користувачів мінеральних ресурсів), що надають інформацію про використання природного капіталу та його виснаження, що збільшує інформаційну цінність звітності, ї̈ прогнозні характеристики і набуває особливого значення при прийнятті управлінських рішень у сфері раціонального використання природного капіталу.

Ключові слова: екологічні інновації, природний капітал, корисні копалини, користувачі надр.

Manuscript received: 17.10 .2018

(C) The author(s) 2018. This article is published with open access at Sumy State University. 